TITLE:

\title{
Socio-technical and political economy perspectives in the Chinese energy transition
}

$\operatorname{AUTHOR}(S)$ :

Mori, Akihisa

\section{CITATION:}

Mori, Akihisa. Socio-technical and political economy perspectives in the Chinese energy transition. Energy Research \& Social Science 2018, 35: 28-36

\section{ISSUE DATE:}

2018-01

URL:

http://hdl.handle.net/2433/253581

\section{RIGHT:}

(c) 2017. This manuscript version is made available under the CC-BY-NC-ND 4.0 license

http://creativecommons.org/licenses/by-nc-nd/4.0/; The full-text file will be made open to the public on 1 January 2020 in accordance with publisher's 'Terms and Conditions for Self-Archiving'; This is not the published version. Please cite only the published version.; この論文は出版社版でありません。引用の際には出版社版をご確認ご利用ください。;A part of this PDF was redacted for privacy protection. 個人情報保護により非表示の部分があります. 


\title{
Socio-technical and Political Economy Perspectives in the Chinese Energy Transition
}

\author{
Akihisa Mori \\ Graduate School of Global Environmental Studies, Kyoto University, 606-8501 Kyoto, Japan \\ Email:
}

\section{Bibliography}

Akihisa Mori is an associate professor at the Graduate School of Global Environmental Studies, Kyoto University and serves as a secretary general of the East Asian Association of Environmental and Resource Economics. He has published and edited several books on environment and development, policy and governance, including Green Growth and Low Carbon Development in East Asia (with F. Yoshida, Routledge, 2015), The Green Fiscal Mechanism and Reform for Low Carbon Development: East Asia and Europe, (with P. Ekins et al., Routledge, 2013) and Environmental Governance for Sustainable Development: An East Asian Perspective (United Nations University Press, 2013).

\section{Abstract}

Electricity systems are so strongly path dependent and deeply embedded in society that vertically integrated monopolistic or oligopolistic supply are justified. However, over-incentivize for capacity investment, excess dependency on fossil fuel, inefficient supply, and lack of customized services, accountability and participation raise dissatisfaction with the prevailing system, urging system transition. Given high potential of renewable energy in breaking the lock-in and generating positive feedback effects, this paper aims to explore how niche innovators and incumbents capitalize on their resources and power to create, augment or weaken prevailing political path-dependencies and lock-in of the prevailing electricity supply system to prospect a future energy transition, taking China as a case. Main findings are: (a) renewable energy has generated feedback effects in China; (b) regime actors have capitalized on their resources and power to organize alliances to be consistent with the government policy orientation while blocking institutional reforms for energy transition; and (c) their resources and power are derived from the monopolistic or oligopolistic electricity supply system and the government price control, both of which are justified for the sake of energy security and economic stabilization.

\section{Keywords}

energy system, socio-technical transition, political economy, China 


\section{Acknowledgement}

The author is grateful for the productive comments given by the internal and external reviewers. This paper are funded by the Japan Society for the Promotion of Science (JSPS) No.26281061 entitled "Energy and climate change policy in China and its impacts on energy exporting Asian countries,” and JSPS No.16K00680 entitled "Effect of emission trading scheme on carbon emission reduction in China”. 


\section{Introduction}

Electricity systems are featured by sunk investments, high entry barriers, long operating lifetimes and complementary capital investments [1]. They are also strongly path dependent and deeply embedded in society in terms of norms, values, laws, modes of governance, social relations and culture [2]. These features have justified vertically integrated monopolistic or oligopolistic supply system of electricity. They enable incumbent suppliers to capitalize on the excess rents to gain comparably large power and resources to pursue regulatory capture [3], to compensate opposition stakeholder groups [1], and to tame the media to propagate legitimacy of the prevailing regime widely to the population [4]. Longer reign of ruling party-incumbent supplier alliance ensures stable supply of excess rents, further reinforcing the prevailing socio-technical regime [3]. This makes the regime be prone to technological and institutional lock-in, and become so economically, institutionally and politically entrenched that is difficult to reconfigure [5].

The system also generates a number of problems that dissatisfy the society. These include: full cost pricing that over-incentivize capacity investment and fossil fuel and/or nuclear fuel consumption; inefficient supply and high electricity price that may harm industrial competitiveness and/or income distribution; lack of customized services; and lack of accountability and participation [6].

Given strong path dependency, deep embeddedness in society, and self-reinforcing incumbents, reconfiguration of the prevailing electricity is likely to take several decades [7]. Creating, maintaining and funding a long-term policy framework are indispensable to sustain momentum toward reconfiguration [8].

Renewable energy can potentially break the lock-in and reconfigure the prevailing electricity regime [1]. First, it can increase competition and diversity into the monopolistic or oligopolistic market. It will eventually alter the prevailing market dynamics within the electricity sector as its generation cost approaches grid parity. Secondly, such competition and diversity squeeze excess rent to the incumbent suppliers, making them incapable of compensating opposition stakeholder groups and of propagating the population. Finally, it can foster emerging local industry poised to benefit from increased renewable energy growth.

Renewable energy in China is likely to satisfy these conditions. First, China's deployment of renewable energy outpaced the government target, which showed upward revisions ${ }^{1}$. The rapid deployment convinces the Energy Research Institute (ERI) of the National Reform and Development Committee (NDRC) to make a scenario analysis of a 50\% renewable energy penetration in 2050 [9]. Second, it has created exporting industries in renewable energy on a greater scale [10]. Third, the government has sufficient budget to play a leading role in supporting the development of renewable energy technologies throughout from prototype to commercial viability 
stages [8], and in limiting the price hike to consumers. Finally, it can learn from the experiences from developed countries and acknowledge both the political opportunities and potential traps that arise from policy design [7]. In reality, non-fossil fuel has increased its proportion in total primary energy consumption from $8.6 \%$ in 2010 to 12\% in 2015 and $13.3 \%$ in 2016 [11].

However, transition of energy system causes hard-fought inter- and intra-scalar contestations between old and new institutions, agents and technologies [12]. Incumbents capitalize on power and resources to block off development of sufficient network capacity, system-balancing facilities and strong demand management that are required to stabilize a hybrid system of fossil fuel-based and renewable electricity [13]. It is by far easy to go beyond the hybrid system toward more sustainable pathway that is featured by either load balancing or region-wide super-grid, as either pathway requires changes in the basic architecture of the prevailing system, guiding principles, beliefs and practices [2][14], including baseload power and reliability [15]. This poses inherent limitations on rapid change [16].

Against this backdrop, this paper aims to explore how niche innovators and incumbents capitalize on their resources and power to create, augment or weaken prevailing political path-dependencies and lock-in of the prevailing electricity supply system to prospect a future energy transition, taking China as a case. It introduces political economic perspective in the socio-technical transition to use as analytical framework, and makes extensive review of published research papers and relevant news reports to provide evidence.

The remainder is organized in four sections. Section 2 makes a literature review to provide justification on the use of both perspectives as analytical framework. Section 3 presents results of the analysis, followed by discussion to draw out implications for transformation of electricity supply system in section 4 . Section 5 offers conclusions and implications for future electricity regime in China.

\section{Political Economic Perspective of Socio-technical Transition}

A number of ex ante quantitative analysis of China's energy and climate change policies has been made to draw out energy implications for the long-term GHG emissions reduction targets. Earlier researches pointed out China's possibility of peaking carbon emissions around 2035 [17] or in 2050 [18] with 6-7\% annual economic growth rate. However, they just listed up technological measures [19] that are required to attain the targets without regard to how and to what extent they should be operationalized. Recent scenario analysis shows the amount of coal consumption reduction that is required to attain the carbon emissions reduction target, air quality target, and water resources targets in 2020 [20]. However, their policy implications are divergent: some insist stronger efficiency improvement and structural adjustment [21], others recommend development 
and efficient system operations of transmission infrastructure, power trading in the market, flexible generation capacity, energy storage technology, and demand-response mechanisms [9] [22].

A group of ex-post empirical analysis has been made to explore the effectiveness of energy and climate change policies. Most of them employ decomposition analysis to confirm the significant contribution of industrial structural change and efficiency improvement to the reduction in energy and carbon emission intensities [23][24][25]. Contrary to the estimate that anticipates larger carbon emission reduction with smaller welfare loss in carbon tax with/without revenue recycling than in energy tax [26], energy intensity target, not the carbon intensity target proves to be binding to both energy and carbon emissions intensity reduction in the $12^{\text {th }}$ Five Year Plan (FYP) period [27]. While identifying the power sector's active reduction as the main factor, they do not explore how power sector addressed to the underlying mechanisms that create the technological and institutional lock-in.

The other group explores enabling factors of the emergence of wind power and solar photovoltaic (PV) manufacturing, with special focus on the role of technological transfer [28][29], government industrial fostering policies [30][31][32], renewable energy deployment policies [10], and technological capacity and market conditions [33]. Some go further to analyze underlying causes of renewable curtailment as a side effect of increasing renewable energy [34], proposing reform options [35]. However, they do not fully analyze political, economic, social and institutional barriers that make it difficult to move out of lock-in.

The socio-technical transition perspective provides a suitable theoretical idiom to explore change processes [14], and practical toolbox of techniques to encourage collaboration among niche innovators [36]. It views supply system of electricity as a socio-technical regime consisting of the rules and routines embedded in infrastructure, markets, technology, politics, knowledge and meanings [37]. It defines a transition as a long-term fundamental change (irreversible, nonlinear, multi-leveled and systemic) in the culture (mental maps, perceptions), structures (formal institutions and infrastructure systems) and practices (use of resources) of a societal system [38]. The multi-level perspective adds three levels of socio-technical system - the niche, the regime and the landscape-, and defines the change in the socio-technical regime as the outcome of multi-dimensional interactions between radical niche innovations, an incumbent regime and an external landscape [37]. It emphasizes a pathway whereby radical innovation emerges in niches and breaks through and overthrows the existing regime in a specific way: (a) niche innovations build up internal momentum through learning processes, price/performance improvements and support from powerful groups, (b) changes at the landscape level create pressure on the regime, revisiting the orientation of innovation and the way technologies are deployed, and (c) destabilization of the regime opens windows of opportunity for niche innovations, as well as struggles among rival 
commercial groups over regulation and property rights [13][39].

This framework, however, focuses too much on innovation and technologies, which results in a limited conceptualization of power and politics [40], market competitiveness [7] and governance between different scales and generations [41]. Politics and power play important roles in how pathways are shaped, which pathways win out and why, and who benefits from them [42] through changes to laws, rules and expenditures. Such changes can only be engineered through political processes, and legitimized and enforced through institutions [40]. This is why political economy perspectives should be introduced into the multi-level perspective of the socio-technical transition [43].

Net positive feedback effects that renewable energy policies are likely to generate also require political economy perspectives in the analysis of energy transition. Feedback effects can be classified as technology and policy ones. Technology feedback effects refer to the modification of political costs and options [44], and the changes in norms, policies, regulations and prevailing institutions [45]. Policy feedback effects, in contrast, refer to the distribution of resources and the creation of material incentives to create or strengthen particular social interest groups, the transformation of state capacities and institutions to affect later prospects for policy implementation, and the changes in the interests, identity and political participation of large group of people to mobilize support [46]. Both effects can create or augment prevailing political path-dependencies [47] and carbon lock-in [48]. Nonetheless, renewable energy policies have more often than not enhanced market competitiveness of renewable energy generators to obtain a certain market so that they can be economically self-sustaining and to create constituencies for their own implementation and expansion [7].

In order for renewable energy to obtain sufficient bargaining power against the prevailing regime, as well as to gain the technological and policy feedback effects, alliances needs to be created between those who have different motives or priority but is willing to join the supporting community of innovative power, and with transformative potentials [1][49]. They have to be kept together and to be expanded over time [50], in order to protect a favorable policy framework until niche innovation become economically self-sustaining [51].

In line with these arguments, this paper introduces political economic perspectives in socio-technical transitions to analyze how the emergence of renewable energy changes bargaining powers between them and how its change affects the pathway and speed of transition. The combination of two perspectives also allows this paper to explore if the on-going policy response generates short-term and superficial solutions or addresses the underlying mechanisms [52]. Given that the nature of underlying institutions and dominant ideas are likely to play a major role in designing policy and shaping the speed and likely success or failure of transformations [7], it is 
relevant to analyzes how landscape developments destabilize underlying institutions and dominant ideas first, and then explores how niche innovators capitalize on the destabilization to emerge and transform the prevailing regime. This approach suits especially well for countries where the government plays the role of 'entrepreneurial' risk-taking in launching specific green technologies like China [8].

\section{Landscape developments in China and the regime's reactions}

\subsection{Landscape developments}

Five landscape developments are worth noting that destabilized the prevailing electricity regime (Table 1).

The first development is the accelerated transition to market economy. The 1992 Southern Tour Lectures by Deng Xiaoping spurred economic growth that heavily depended on energy-intensive sectors. This jumped up energy demand and energy import from unregulated international markets. On the other hand, China's power sector was characterized by a socialist style planning with no separation between ownership and management, and co-existence of a monopolized, vertically integrated supply system of electricity by state enterprises and a large number of small and cheap, but inefficient local coal powers and grids established in the 1980s. This widened disconnection between the policy needs of a dramatically changed and increasingly market-oriented energy sector and the command-and-control oversight and regulation [53], destabilized the latter.

The second development is the rising concern about energy security. China's power sector grappled with reliability issues and a "boom/bust” supply cycle that fluctuated regularly between periods of highly disruptive supply shortage and inefficient overcapacity [54]. Allowing foreign investment in the 1990s did not solve this problem due to the government strict restriction and regulations, as well as investors' perceived high risk to regulatory changes [55]. While the target responsibility system was implemented for mandated shutdown of small and inefficient local coal powers, it resulted in the chronic supply shortages amid the economic recovery induced by the accession to China's World Trade Organization. The government was stuck in a dilemma between expansion and/or revival of inefficient capacity at the cost of air pollution, and the continuous scrap of inefficient capacity and improvement of air pollution at the expense of sustained future industrial growth [56]. Meantime, local governments only supported and approved investments in a large number of new small-scale coal plants, as well as large-scale plants that were never approved and were technically illegal [34]. Coupled with strict coal price regulation that increased financial deficit of the coal industry, this local government stance spurred coalmines' ignorance to the safety and health concerns, causing nine thousand coalmine accidents and the death of twenty thousand workers in $2000-05^{2}$ [57]. 
The third one is the emergence of global climate governance. China softened its hostile stance on greenhouse gas (GHG) emissions reduction when it recognized that clean development mechanism (CDM) projects can bring large windfall commercial profit and other co-benefits such as easier access to foreign capital, renewable energy adoption and deployment of domestic environmental technology [51]. International community propped up pressures against non-binding targets for emerging economies, especially China that had surpassed the United States to be the world largest emitter in 2007. In the United States, border carbon adjustment bills were submitted in the Congress to impose carbon tax on China's exports [58].

The fourth is worsening air pollution and acid rain in China. Despite a number of regulations specifically targeted at coal power in the $11^{\text {th }}$ FYP period (2006-10) [56], massive amount of visible air pollution has spread out in Beijing-Tianjin-Hebei Province, the Yangtze River Delta and the Pearl River Delta since 2011, raising health concerns. This led to Air Pollution Prevention and Control Action Plan (2013-17) that required forced closure and/or inhibition of new small-scale commercial boilers, industrial plants in heavy industry, and non-utility power generation plants; restriction of the use of high sulfur and ash coal in major cities and their long-distance transport of them. The Chai Jing's 2015 104-minute documentary Under the Dome gave an additional momentum for framing air pollution as an urgent health issue using compelling visuals, opening doors to behavioral and policy ramifications with transformative potential [59]. Health concerns became so immense that the government recognizes worsening air pollution as a threat to the legitimacy of the Communist Party of China (CPC) [60].

Finally, the economic downturn intensifies contestation between renewable and incumbent power suppliers. Both suppliers can earn a profit as long as their capacity investments are required to meet the growing electricity demand. However, the growth of electricity demand slowed down to $0.5 \%$ in 2015 in contrast with 3.7\% in 2013 [61]. Under the new economic condition, continuous investments by both suppliers will create an excess capacity, which will trigger competition over the demand and contestation between them.

\subsection{Policy responses}

These landscape developments prompted the state and the CPC to adjust energy, climate and air pollution control policies to control the destabilization of the prevailing regime. To close the gap between increasing market economy and the command-and-control oversight and regulation, it reorganized the power sector in 2002. Generation and transmission/retailing was unbundled to create a diverse set of generation companies and two state grid companies to replace highly fragmented grids structure. The State Electricity Regulatory Commission (SERC) was established as an independent regulator, but was not given sufficient independent power to oversee new market 
structures [54]. However, strong political resistance as well as concerns over power shortage halted the government effort towards competitive wholesale market. As a result, several large state-owned power generation companies, including the Great Five Power Groups dominate generation, and the state grid companies keep double monopoly status_as the only buyer to producers and the only supplier to consumers. The NDRC kept controlling the price [34].

To enhance energy security and to address safety and health concerns, the government implemented a number of stick and carrot programs to the energy industries. The Small Plant Closure Program was implemented to facilitate the consolidation of coal power and to accelerate replacement with coal combined heat and power $(\mathrm{CHP})^{3}$ [56]. The Environmental Impact Assessment Act empowers the State Ministry of Environmental Administration (SEPA) to suspend illegal projects, and reject or postpone review process of power plant projects proposed by incompliant generators [62]. Beside forced consolidation of coal industry and the requirements for safety and resource recovery, coal price reform was also initiated that consisted of relaxation of price control; imposition of royalty for concession and resource compensation fee; replacement of resource charge to resource tax to increase the rate. A pilot coal charge was implemented in Shanxi province that would be recycled for safety and health investment in mining [63]. A series of policies, measures, incentives and programs were also implemented for energy conservation at end-uses, including: a $20 \%$ and $16 \%$ reduction target for energy intensity in the $11^{\text {th }}$ and $12^{\text {th }} \mathrm{FYP}$; a Top 1000 Energy Consuming Enterprise program, which was expanded to 10000 installations in the $12^{\text {th }}$ FYP; and a cap on primary energy and coal consumption.

The government also changed the interpretation of additional development of oil and gas around the world as an enhancement of Chinese energy security through increasing global energy security [64], justifying its large energy import. In line with this reinterpretation, coal import ban was lifted so that industrial end users located in coastal regions could access to a cheaper coal from Australia and Indonesia [65]. State oil companies are provided large subsidized loans to seek for and obtain oil and gas fields in foreign countries [66].

However, the international hike in energy price in the mid-2000s alerted the unsustainability of fossil fuel [67]. This made the government to place priority on new energy and energy efficiency that could safeguard energy security, rather than technologies that purely serve the purpose of emission reduction. Climate change was reframed as an issue of development [68], and became a part of its overall energy strategy whose fundamental goal is to ensure sustained economic growth and prosperity. Renewable energy was also reinterpreted as new economic growth point and a fulcrum for international competitiveness [69]. With these reframing, the government perceived net positive effect of GHG emissions reduction on economic growth and poverty reduction, releasing voluntary emissions reduction targets in the UNFCCC and described them in the FYPs. 
Worsening air pollution prompted the government to impose a ceiling on national coal consumption. The $13^{\text {th }}$ energy FYP set out a cap on coal consumption and targets for generation capacity of wind and solar power. To attain these targets, the government announced an increase in natural gas power and ultra-super critical coal power, and implemented coal consumption standards for power plants [70]. It also imposed restriction on import and local sale of coal with high ash and sulfur content [71], and issued a notification that accelerates consolidation while imposes strict regulations on the operation dates and bans new mining and renovation projects.

\subsection{Market competitiveness}

The reinterpretation of renewable energy justified government support to foster and enhance market competitiveness of domestic wind turbine [72]. It implemented national concession program in 2003 featuring competitive bidding for large wind power projects, preferential treatment and subsidies to winners ${ }^{4}$, and high local content requirement that de facto excluded foreign developers ${ }^{5}$. State-owned banks were coordinated to offer large financial and investment incentives to state-owned or state-connected enterprises [32]. State grid companies were mandated to guarantee purchase of the generated wind power over 25 years at the winning price. These measures reduced risk and increased perceived profit of wind power projects, incentivizing state-owned companies to underbid in the selection process to expand generation capacity. While license agreements with foreign companies restricted Chinese manufacturers from their upgrading technology and widening sales market, they bypassed these restrictions by acquiring technology licenses from second-tier foreign manufacturers who had lost in the competition in the European market and had therefore been willing to sell licenses at a cheaper price. This increases market competitiveness of Chinese wind turbine manufactures in both domestic and international markets, and enables wind power generators to supply electricity at a cheaper price.

By contrast, the central government failed to foster state-owned solar PV manufacturers [58]. The national concession program for solar PV simply squeezed out the already emerged domestic private manufacturers from domestic market, redirecting them towards the export market. Backed by in kind support from local governments and subsidized loans from the China Development Bank [73], they capitalized on renewable energy deployment policy in foreign countries [10] to realize economies of scale, dominating a lion's share in the world's PV module and cell market by 2012 [69]. This kicked first-tier German and US manufacturers out of the market, and got them into bankruptcy. This raised anti-dumping measures by the United States, forcing some Chinese manufacturers to go bankrupt as well. This prompted the central government to expand the scope of the feed-in-tariff to include solar power so that they can tap the domestic market to get out of financial distress [68]. 
In the meantime, coal price have been raised twice during 2000-08 [63], and further increased in 2009-10 [74] as a result of the coal price reform. The price hike triggered conflicts of interest between coal industry and coal power: it enabled coal industry to invest in capacity expansion and safety in mines, but made coal power fall into financial distress under the wholesale price control. This led the government to implement special treatment on coal price, including an exemption of coal power from the 2015 restriction on import and local sale of coal with high ash and sulfur content [75], and the suspension of local governments' approval of new coalmines during the soaring coal price in the latter half of 2016.

As a result, the price gap between coal power and renewable electricity has not closed so rapidly. The feed-in tariff for onshore wind power is $0.51-0.61$ yuan/kWh and that for solar PV is 1 or 1.15 yuan $/ \mathrm{kW}$, while on-grid tariffs for coal power are about $0.24-0.48$ yuan $/ \mathrm{kWh}$ and 0.14-0.40 yuan/kWh for hydropower in 2015 [76]. Low coal price eventually slows down energy transition. Despite the rapid increase, wind and solar power account only for 3 and $1 \%$ in total electricity generation, while coal power remains more than $70 \%$ in 2014 (Figure 1).

\subsection{Power exercises}

Rapid developments in renewable energy provoked severe contestations and power struggles between renewable electricity generator and coal power generators and state grid companies, resulting in high level of wind and hydropower curtailment. National average wind curtailment rate was one-third in 2011 [77]. While it fell down to 8\% in 2014 [78], but resurged to reach 15\% in 2015 [79], and 13\% in 2016 [80]. Gansu and Xinjiang saw wind curtailment by 39\% and 32\% in 2015 [80], and Yunnan did hydropower curtailment by more than 25\% of the potential generation in 2013 [34]. Besides, solar curtailment becomes significant [81]: it rose 50\% over 2015 and 2016 nationwide, and more than $30 \%$ of solar power failed to reach the grid in Gansu and Xinjiang-Uygur provinces [82].

Provincial governments, especially those who have relied revenues and employment significantly from incumbent coal powers and coalmines stand as a constitutive power. They ordered wind farms to shut down or to buy production quota from coal powers to rescue their financial distress [83]. Discrimination against renewable energy is especially harsh in Xinjiang-Uygur, Gansu and Yunnan provinces. The Xinjiang-Uygur autonomous region imposed a levy of 0.2-0.25 yuan per kWh on wind power and used the revenue to support coal power. Yunnan province demanded wind power and hydropower generators to transfer some of their revenues to coal power. Gansu province requires renewable power generators to sell electricity in competitive direct power purchase deals, which results in much lower prices than the feed-in-tariff, while coal power generators are allowed to sell at the higher benchmark price. 
The central government became cautious in exercising transformative power. At first, it defined the underlying causes of renewable curtailment as breakdowns in the planning process, namely: lack of coordination between wind generation and transmission planning; mismatch between project approval and transmission planning timelines, and lack of local demand or transmission export capacity; lack of balancing sources; and lack of flexible pricing mechanisms and optimized dispatch [84]. In this definition, the government and the CPC released the "Deepening Reform of the Power Sector” and its implementation documents so that grid companies can implement demand-side management (DSM) and end-use energy efficiency programs [35]. It also released Document No.9 "Further Strengthening the Institutional Reform of the Electric Power Industry” to start research on challenges such as electricity pricing mechanism that eliminates unreasonable cross-subsidies, and dispatch plans that place priority on renewable electricity. A social experiment on energy efficient dispatch in the Guaxi province was performed, but proved to increase imbalances and center-provincial tensions in the current system [85]. Alternatively, the central government issued a regulation that mandated the two state grid operators to give priority toward clean energy over coal, setting a minimum limit of $5 \%$ of electricity on the transmission grid that must come from wind, solar and biomass. Nonetheless, it has not strictly punished them for curtailment [77]. The central government refuses their requests to pass on additional costs for correcting the geographical imbalance and developing transmission infrastructure to consumers, and does not sufficiently compensate this investment. This resulted in the suspension of new wind power construction approvals and access to grid connections in six provinces of Heilongjiang, Jilin and Gansu provinces, Inner Mongolia, Ningxia Hui, and Xinjiang-Uygur autonomous regions [86]. This measure angered the China Renewable Energy Society, which filed lawsuits against these provincial governments for violations to the guaranteed purchase principle in the Renewable Energy Law, claiming the loss to wind power generators amounting to 18 billion yuan [87][88].

\section{Discussion}

4.1 China's electricity system from a socio-technical transition perspective

The above analysis shows that it is only as long as energy shortage is perceived as a most serious energy challenge and when energy security is placed as top priority that the prevailing regime welcomes emergence of renewable energy as a niche innovator to stabilize the regime that is destabilized by landscape developments. When the government initiated to foster wind turbine manufacturers and to deploy wind power, coal power and state grids regarded it as complementary to address power shortage and rural electrification, rather than as a competitor. Once the generation capacity far exceeds the demand, and renewable electricity arrives at grid parity price, however, incumbents regarded renewable energy as a threat to their vested interests and the prevailing regime. 
They capitalize on their resources and power to block off renewable energy from generating positive feedback effects that will advance further energy transition.

In China, the economic downturn since 2015 and the subsequent slowdown of energy demand growth marked a turning point. China got significant surplus generation capacity in that year: it is estimated to have a national effective reserve margin of $25-28 \%$ in 2014 , much larger than $15 \%$ in US [89].

Identical business model intensifies conflict of interests between renewable energy and incumbent coal power generators. Renewable generators are incentivized to generate whenever possible to earn a feed-in tariff [34]. Coal power generators are also incentivized to expand capacity and to operate their maximum annual allocation of hours under the government-regulated power allocation scheme [90]. They are required to operate a planned number of fully loaded hours to cover both variable and capacity costs [91]. All thermal plants are allowed to receive the same number of operating hours, regardless of their heat rate or economics [92]. Very limited peaking generators, coupled with no formal, objective criteria to evaluate transmission projects for investment [34] motivated them to invest in capacity.

However, the supply system was created and embedded into a society that favored coal power. Priority on grid connection is given to coal power while no environmental criteria is applied to decide units to be curtailed [91]. Neither coal power not state grid companies bear the cost of curtailment because there is no legislation that clearly demands compensation for curtailment [93]. Under this rule of game, the transition to hybrid system provokes hard clash, resulting in the unilateral curtailment of renewable energy that has smaller resources and power.

\subsection{China’s electricity system from the political economic perspective}

This does not imply that renewable energy in China failed to gain positive policy feedback effects and to organize alliances. The emergence of renewable energy manufactures has cut down investment and generation cost of renewable energy. Coupled with large import of natural gas, this reduces the political cost of emissions reduction, enabling the government to revise the renewable energy target upward. This pushes investments in renewable energy capacity, increasing the amount of renewable power generation (Figure 1).

It is important to note, however, that coal power and state grids have also capitalized on their resources and power to organize alliances to augment prevailing power supply system and to maintain their competitive edge. In the period of rapid electricity growth, wind curtailment, which had been reported as serious in 2010 and 2011, was resolved with rapid growth in electricity demand (Figure 2a).

When landscape was developed to take China into a stagnant demand growth, however, large 
state-owned coal power has mobilized resources and power to prop up the prevailing regime. They lobbied the central and local governments [34] to get approval for both coal and renewable generation projects [94]. They added 35GW of coal generation capacity in 2014 compared to an end-of year total system generation capacity of 1360GW [90] even after wind curtailment had been recognized as serious problem. To get approval as well as maintain its support, they shifted coal power projects toward ultra-supercritical and CHP that are cleaner, more efficient but less flexible, crashing hard with renewable powers [95]. Coal power has also lobbied hard against plans proposed by the coal association to restrict imports [75], getting exemption for coal power from the 2014 coal ban. At the same time, they fiercely resist reductions in operating hours that result from increased renewable energy generation. This discourages investment in flexible resources.

Coal-rich local governments have supported their activities. They took protective measures to avoid economic loss and unemployment that is triggered by government initiative for industrial overcapacity reduction, and the coal consumption cap in the $13^{\text {th }}$ FYP [96], as the government estimates these measures would make 1.3 million coal sector workers redundant [97].

State grid companies de facto join in the alliance of coal powers. They have enhanced their power and influence, especially in the negotiations with investors or operators, through active integration of vast number of rural grids into their networks, consolidation of the major grids into fewer and larger ones [94]. One grid policy of provincial governments helps their consolidation and reinforcement of double monopoly status [98]. Under this context, they have ignored the construction of the $220 \mathrm{kV}$ and $500 \mathrm{kV}$ network connecting wind power to the grid [99], and interconnection among provincial grids that enable renewable energy to be integrated into the system without impairing reliability and investing in costly and lengthy transmission lines [34]. Such grid infrastructure development and system balancing are not government priority, require huge amount of investment costs ${ }^{6}$, and not particularly suitable for coal power [100]. Rather, they have developed interconnecting individual plants with provincial grids [34] and ultra-high-voltage (UHV) transmission network ${ }^{7}$ [96] that are in line with the government initiative on long-distance electricity transmission from renewable-rich provinces to relatively low coastal provinces.

State grid companies are also suspected to capitalize on political power to exclude independent system operators from the power sector reform plan, which enables them to continue to take charge of making dispatch plans and to influence over other participants, including power generation companies and consumers [101]. Given that the government-regulated power allocation scheme prompt energy dispatching centers to set the maximum amount of wind energy a day ahead of time, at a level fixed quite low due to the variability of the wind energy supply [99], they will not exercise power relation in favor of renewable energy generators. All of their activities intensify alliance that augments prevailing power supply system (Figure 2b), resulting in a large renewable 
curtailment in 2015-16.

\section{Conclusions}

This paper aims to explore how niche innovators and incumbents capitalize on their resources and power to create, augment or weaken prevailing political path-dependencies and lock-in of the prevailing electricity supply system to prospect a future energy transition in China, by introducing political economy perspective in socio-technical transition. The findings can be summarized as follows.

First, renewable energy has generated feedback effects in China. Several landscape development have destabilized the prevailing electricity supply system to open the window for renewable energy manufacturing to emerge as a niche innovation, and their emergence prompted the government to release ambitious renewable energy targets, supporting their further deployment and falling cost.

Second, incumbent coal power have capitalized on their resources and power, to organize an alliance to be consistent with the government policy orientation while blocking institutional reforms for energy transition, at the cost of high renewable curtailment.

This implies that China will stay at the hybrid system with a large renewable curtailment as long as the government keeps strict price control and disregards system operation efficiency. The coal consumption cap will merely result in coal price hike and forced shutdown of coal power and mines. UHV and long-distance transmission may result in proliferation or consolidation of coal power without simultaneous development of the $220 \mathrm{kV}$ and $500 \mathrm{kV}$ network connecting renewable power to the grid. While the government announced to fund 100 billion yuan for unemployment [102], its financial support for foreign business of coal industry and power poses a risk of international displacement of coal consumption and carbon emission [103].

The unfavorable contestation to renewable energy prevails wherever vertically integrated, monopolistic or oligopolistic electricity supply system and/or government price control have long been justified for the purpose of energy security. The political, economic and institutional cost of energy transition becomes high, since the electricity supply system has been long developed by monopolistic or oligopolistic incumbent suppliers in their favor [94]. This justifies discriminatory grid access against renewable electricity, even if renewable energy becomes so competitive in the market that it can be self-sustaining ${ }^{8}$. The government may perceive liberalized wholesale market with an independent regulator and a formal, transparent rate making process as a loss of political instrument to control inflation, thus legitimizing their governance.

The lack of successful transition experience also makes governments in East Asian countries reluctant to reframe renewable energy as an electricity supply system for energy security in the face of output uncertainty and variability of renewable energy. This implies that it is not until Europe or 
North America demonstrates the successful transition to renewable energy-centered electricity supply system that they go beyond the hybrid system to advance energy transition.

\section{References}

[1] Schmidt, T.S., T. Matuo, and A. Michaelowa, Renewable energy policy as an enabler of fossil fuel subsidy reform? Applying a socio-technical perspective to the cases of South Africa and Tunisia, Global Environmental Change (2017) http://dx.doi.org/10.1016/j.gloenvcha.2017.05.004.

[2] Verbong, G.P.J. and F.W. Geels, Exploring sustainability transitions in the electricity sector with socio-technical pathways, Technological Forecasting \& Social Change 77 (2010) 1214-21.

[3] Mori, A., Temporal dynamics of infrasystem transition: The Case of Electricity System Transition in Japan, forthcoming in Technological Forecasting \& Social Change (2017), http://dx.doi.org/10.1016/j.techfore.2017.05.003.

[4] Honma, R,. Nuclear Power Propaganda, Iwanami Shinsho, Tokyo (2016) (in Japanese).

[5] Fouquet, R., Path dependence energy systems and economic development, Nature Energy 1 (2016) 1-5, http://dx.doi.org/10.1038/nenergy.2016.98.

[6] Takahashi, H., Market Liberalization of Electric Utilities: What Do We Need Unbundling of Power Grid After 3.11?, Nihon Keizai Shinbunsha, Tokyo (2011) (in Japanese).

[7] Lockwood, M., The politics of dynamics of green transformations: Feedback effects and institutional context, in Scoones, I., M. Leach and P. Newell (eds.) The Politics of Green Transformation, Routledge, Oxon (2015) 86-101.

[8] Mazzucato, M., The green entrepreneurial state, in Scoones, I., M. Leach and P. Newell (eds.) The Politics of Green Transformation, Routledge, Oxon (2015) 134-52.

[9] Energy Research Institute (ERI), China 2050 High Renewable Energy Penetration Scenario and Roadmap Study, Beijing http://www.efchina.org/Attachments/Report/report-20150420/China-2050-High-Renewable-En ergy-Penetration-Scenario-and-Roadmap-Study-Executive-Summary.pdf, accessed on June 23, 2017.

[10] Groba, F. and J. Cao, Chinese renewable energy technology exports: The role of policy, innovation and markets, Environmental and Resource Economics 60 (2015) 243-83.

[11] Wang, B. China 2020 and 2030 energy plans, Next Big Future (April 25, 2017), https://www.nextbigfuture.com/2017/04/china-2020-and-2030-enegy-plans.html, accessed on June 23, 2017.

[12] Rock, M.T. et al., A hard slog, not a leap frog: Globalization and sustainability transitions in 
developing Asia, Technological Forecasting \& Social Change 76 (2009) 241-54.

[13] Foxon, T.J., G.P. Hammond, and P.J.G. Pearson, Developing transition pathways for a low carbon electricity system in the UK, Technological Forecasting \& Social Change 77 (2010) 1203-13.

[14] Geels, F.W. and J.W. Schot, Typology of sociotechnical transition pathways, Research in Policy 36 (3) (2007), 399-417.

[15] Takahashi, H., Reform of electricity system in progress: toward stable supply under the distributed electricity system, in Oshima K. and Takahashi H. (ed.) Distributed Energy System, Nihon Hyoronsha, Tokyo (2016) 215-37 (in Japanese).

[16] Smith, A. and Raven R., What is protective space? Reconsidering niches in transition to sustainability, Research Policy 41 (6) (2012) 106-19.

[17] Energy Research Institute (ERI), China's Low Carbon Development Pathways by 2050 (in Chinese). China Science Press, Beijing (2009).

[18] Dai, Y., Y. Zhu and Q. Bai, China 2050: Scenarios of energy consumption and carbon emissions, in Xue, J., Z. Zhao, Y, Dai, and B. Wong (eds.), Green Low-Carbon Development in China, Springer, Heidelberg (2013) 171-88.

[19] CCICED, China's Pathway Towards a Low Carbon Economy, CCICED Policy Research Report 2009, Beijing,

(2009).

http://english.sepa.gov.cn/Events/Special_Topics/AGM_1/2009agmpp/meetingdoc09/201605/P $020160524222056454853 . p d f$, accessed on June 23, 2017.

[20] China Coal Cap Project, China Coal Consumption Cap Plan and Research Report: Recommendations for the $13^{\text {th }}$ Five-Year Plan, Beijing (2015) https://d2ouvy59p0dg6k.cloudfront.net/downloads/china_coal_consumption_cap_plan_and_re search_report_recommendations_for_the_13fyp.pdf, accessed on June 23, 2017.

[21] Zhang, X., X. Zhao, Z. Jiang, S. Shao, How to achieve the $2030 \mathrm{CO}_{2}$ emission-reduction targets for China's industrial sector: Retrospective decomposition and prospective trajectories, Global Environmental Change 44 (2017) 83-97.

[22] Wang, Z.X., J.J. Zhang, L. Pan, F. Yang and L.N. Shi, Estimate of China's energy carbon emissions peak and analysis on electric power carbon emissions, Advances in Climate Change Research 5 (2014) 181-8.

[23] Xue, J. and Y. Zhu, Analyzing energy conservation and carbon emissions reductions of China's $11^{\text {th }}$ FYP plan, in Xue, J., Z. Zhao, Y, Dai, and B. Wong (eds.), Green Low-Carbon Development in China, Springer, Heidelberg (2013) 31-54.

[24] Zhu, Y., Energy conservation and emissions reduction in energy-intensive and high-carbon sectors, in Xue, J., Z. Zhao, Y, Dai, and B. Wong (eds.), Green Low-Carbon Development in 
China, Springer, Heidelberg (2013) 55-80.

[25] Chen, S. Energy, Environment and Economic Transformation in China, Routledge, Oxon (2013).

[26] Li, A. and B. Lin, Comparing climate policies to reduce carbon emissions in China, Energy Policy 60 (2013) 667-74.

[27] Cao, J. and V.J. Karplus, Firm-level determinants of energy and carbon intensity in China, Energy Policy 75 (2014) 167-78.

[28] Bai, X., A.J. Wieczorek, S. Kaneko, S. Lisson and A. Contreras, Enabling sustainability transitions in Asia: The importance of vertical and horizontal linkages, Technological Forecasting \& Social Change 76 (2009) 255-66.

[29] De la Tour, A., M. Glachant, and Y. Ménière, Innovation and international technology transfer: The case of the Chinese photovoltaic industry, Energy Policy 39 (2011) 761-70.

[30] Lewis S., Technology acquisition and innovation in the developing world: Wind turbine development in China and India, Studies in Comparative International Development 42 (2007) 208-32.

[31] Buen J. and P. Castro, How Brazil and China have financed industry development and energy security initiatives that support mitigation objectives, in Michaelowa K. and A. Michaelowa (eds.) Carbon Markets or Climate Finance? Low Carbon and Adaptation Investment Choices for the Developing World, Routledge, Oxon (2012) 53-91.

[32] Hochstetler, K. and G. Kostka, Wind and solar power in Brazil and China: Interests, statebusiness relations, and policy outcomes, Global Environmental Politics 15 (2015) 74-94.

[33] Dai, Y. and L. Xue, China's policy initiatives for the development of wind energy technology, Climate Policy 15 (2015), 30-57.

[34] Kahrl, F., and X. Wang, Integrating renewable energy into power systems in China: A technical primer-Electricity planning. Regulatory Assistance Project http://www.raponline.org/wp-content/uploads/2016/05/rap-e3-chinaelectricityplanning-2015-oct. pdf, accessed on June 19, 2017.

[35] Dupuy, M., D. Crossley, F., Kahrl, and K. Porter (2015) Low-Carbon power sector regulation: Options for China, Consultant's report commissioned by the World Bank, Regulatory Assistance Project,

http://www.raponline.org/wp-content/uploads/2016/05/rap-worldbank-lowcarbonpoweroptionsfo rchina.pdf, accessed on June 18, 2017.

[36] Kemps, R., D. Loobach and J. Rotmans, Transition management as a model for managing processes of co-evolution towards sustainable development, International journal of Sustainable development \& World Ecology 14 (2007), 78-91. 
[37] Geels, F.W., Technological Transitions and System Innovations: A Co-evolutionary and Socio-technical Analysis, Edward Elgar, Cheltenham (2005).

[38] Frantzeskaki, N. and H. de Haan, Transitions: Two steps from theory to policy, Futures 41 (2009) 593-606.

[39] Verbong G.P.J. and D. Loorbach, Introduction, in Verbong G.P.J. and D. Loorbach (eds.) Governing the Energy Transition: Reality, Illusion or Necessity? Routledge, Oxon (2012), $1-23$.

[40] Meadowcroft, J. Engaging with the politics of sustainability transitions, Environmental Innovation and Societal Transitions 1 (1), (2011) 70-5.

[41] Lawhon, M. and J.T. Murphy, Socio-technical regimes and sustainability transitions: Insights from political ecology, Progress in Human Geography 36(3) (2011) 354-78.

[42] Scoones, I., P. Newell and L. Leach, The politics of green transformations, in Scoones, I., M. Leach and P. Newell (eds.) The Politics of Green Transformation, Routledge, Oxon (2015) $1-24$.

[43] Geels, F.W., Regime resistance against low-carbon transitions: Introducing politics and power into the multi-level perspective, Theory, Culture \& Society 31(5) (2014) 21-40.

[44] Jordan, A. and E. Matt, Designing policies that intentionally stick: Policy feedback in a changing climate, Policy Science 47 (2014) 227-47.

[45] Verbong, G. and F. Geels, The ongoing energy transition: Lessons from a socio-technical, multi-level analysis of the Dutch electricity system (1960-2004), Energy Policy 35 (2007) 1025-37.

[46] Pierson, P., When effect becomes cause: Policy feedback and political change, World Politics 45(4) (1993) 595-628.

[47] Pierson, P. Increasing returns, path dependence, and the study of politics, American Political Science Review 94(2) (2000) 251-67.

[48] Unruh, G.C., Understanding carbon lock-in, Energy Policy 28 (2000) 817-30.

[49] Avelino, F. and J. Rotmans, A dynamic conceptualization of power for sustainability research, Journal of Cleaner Production 19 (2011) 796-804.

[50] Schmitz, H., Green transformations: Is there a fast track?, in Scoones, I., M. Leach and P. Newell (eds.) The Politics of Green Transformation, Routledge, Oxon (2015) 170-84.

[51] Mori, A. Conclusion: Advancing environmental policy integration, in Mori A. (ed.) Environmental Policy Integration: Reform of the Policy Decision Making Process and Implementation in Transport Sector in Europe and Japan, Minerva Shobo, Kyoto (2013) 255-67 (in Japanese).

[52] Smits, M., Southeast Asian Energy Transitions: Between Modernity and Sustainability, 
Ashgate, Farnham (2015).

[53] Berrah, N., F. Feng, R. Priddle and L. Wang, Sustainable Energy in China: The Closing Window of Opportunity, World Bank, Washington DC (2007).

[54] International Energy Agency, China’s Power Reform: Where to Go, OECD, Paris (2006).

[55] Michaelowa, A., S. Asuka-Zhang, K. Krause, B. Grimm, and T. Koch, The clean development mechanism and China's energy sector, in Harris, P.G. (ed.) Global Warming and East Asia: The Domestic and International Politics of Climate Change, Routledge, London (2003) 109-31.

[56] Mori, A. and T. Hayashi, Transboundary environmental pollution and cooperation between Japan and China: A historical review,” in Ueta, K. (ed.) CDM and Sustainable Development in China: Japanese Perspectives, Hong Kong University Press, Hong Kong (2012) 1-22.

[57] Wang, M.X., T. Zhang., M.R. Xie, B. Zhang, and M.Q. Jia, Analysis of national coal-mining accident data in China, 2001-2008, Public Health Reports 126(2) (2011) 270-75.

[58] Zhang, Z.X., Energy and Environmental policy in China: Towards a Low-Carbon Economy, Edward Elgar, Cheltenham (2011).

[59] Koehn, P.H., China Confronts Climate Change: A Bottom-up Perspective, Routledge, Oxon, 2016.

[60] Ren, B. and H. Shou, H. Introduction: Dynamics, challenges and opportunities in making a green China, in Ren, B. and Shou, H. (eds.) Chinese Environmental Governance: Dynamics, Challenges and Prospects in a Changing Society, Palgrave Macmillan, New York (2013) 1-18.

[61] National Bureau of Statistics, China Energy Statistical Yearbook 2016, China Statistical Press, Beijing (2016).

[62] Wang, $X$. Recent development of environmental law and remaining challenges, in Kitagawa. $H$. (ed.) Environmental Problems, Law and Policy in China, Horitsu Bunka Sha, Kyoto (2008) 26-49 (in Japanese).

[63] Horii, N., Energy: Pricing reforms and the end of low energy price, in Watanabe M. (ed.) The Disintegration of Production: Firm Strategy and Industrial Development in China, Edward Elgar, Cheltenham (2014) 307-33.

[64] Hayashi, K., Conditions for high-performer in international oil and gas upstream industry: A CERA proposal for increasing international competitiveness of Japanese firms, Oil and Gas Review 40 (3) (2006) 33-41 (in Japanese).

[65] Mori, A. Impact of the resource boom in the 2000s on Asian-Pacific resource exporting countries, in Mori, A. (ed.), China's Climate-Energy Policy: Domestic and International Impacts, Routledge, Oxon (forthcoming).

[66] Patey, L., The New Kings of Crude: China, India and the Global Strategies for Oil in Sudan and South Sudan, C. Hurst \& Co. Ltd, UK, 2014. 
[67] Chen G., China’s Climate Policy, Routledge, Oxon (2012).

[68] NDRC, China's National Climate Change Programme, Beijing (2007).

[69] Mori, A., Green growth and low carbon development in East Asia: Achievements and challenges, in Yoshida F. and A. Mori (eds.) Green Growth and Low Carbon Development in East Asia, Routledge, Oxon (2015) 278-304.

[70] Climate Nexus, China's climate and energy policy: Leadership efforts on the road to a low-carbon future, (2015), http://climatenexus.org/learn/international-actions/chinas-climate-and-energy-policy, accessed on December 5, 2016.

[71] Wong, F., China to ban imports of high ash, high sulfur coal from 2015, Reuters (September 15, 2014), http://www.reuters.com/article/us-china-coal-imports-idUSKBN0HB02M20140916, accessed on June 27, 2017.

[72] Horii, N., The wind turbine industry: The role of policy and markets in the catch-up process, in Watanabe M. (ed.) The Disintegration of Production: Firm Strategy and Industrial Development in China, Edward Elgar, Cheltenham (2014).

[73] Sanderson, H. and M. Forsythe, Debt, Oil and Influence-How China Development Bank is Rewriting the Rules of Finance, John Wiley \& Sons (2013).

[74] Guo, S. State of energy in China, Tokyo- Iwanami Shinsho (2011) (in Japanese).

[75] Wong, F. and P. Sonail, China power plants exempt from ban on using low-quality coal: sources, $\quad$ Reuters $\quad$ (September $19, \quad 2014$ ), http://www.reuters.com/article/us-china-coal-idUSKBN0HE0TU20140919, accessed on June 27, 2017.

[76] Lin, B. and J. Li, Analyzing cost of grid-connection of renewable energy development in China, Renewable and Sustainable Energy Reviews 50 (2015) 1373-82.

[77] Fang Y., J. Li and M. Wang, Development policy for non-grid-connected wind power in China: An analysis based on institutional change, Energy Policy 45 (2012) 350-58.

[78] REN21, Renewables 2014 Global Status Report, (2014) http://www.ren21.net/Portals/0/documents/Resources/GSR/2014/GSR2014_full\%20report_low \%20res.pdf, accessed on November 3, 2014.

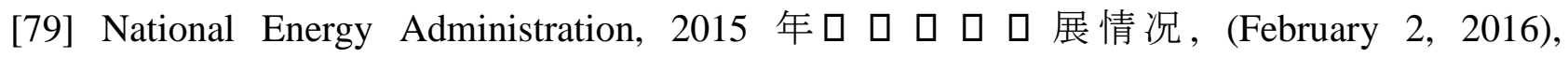
http://www.nea.gov.cn/2016-02/02/c_135066586.htm, accessed on June 20, 2017.

[80] REN21, Renewables 2017: Global Status Report, http://www.ren21.net/gsr_2017_full_report_en f (2017), accessed on June 20, 2017.

[81] Dupuy, M., F. Weston and A. Hove, Power sector: Deepening reform to reduce emissions, 
Improve air quality and promote economic growth, Paulson Institute (2015), http://www.paulsoninstitute.org/wp-content/uploads/2015/09/2-Power-Sector-EN-Final.pdf, accessed on July 8, 2017.

[82] Stanway, D. Update 1-China renewable power waste worsens in 2016 - Greenpeace, Reuters (April 19 , 2017), http://www.reuters.com/article/china-renewables-waste/update-1-china-renewable-power-wasteworsens-in-2016-greenpeace-idUSL3N1HR1HP, accessed on September 11, 2017.

[83] Yang, C-J., Energy Policy in China, Routledge, Oxon (2017).

[84] SERC, Report on Wind Absorption in Key Areas (重点区域风电消纳监管报告), (2012), http://www.eeechina.cn/upload/file/电监会重点区域风电消纳监管报告.pdf, accessed on July 8, 2017 (in Chinese).

[85] Kahrl, F., J.H. Williams and J. Hu, The political economy of electricity dispatch reform in China, Energy Policy 53 (2013) 361-69.

[86] China Daily, New wind power projects banned in six regions due to wastage (February 23, 2017), http://www.chinadaily.com.cn/business/2017-02/23/content_28316786.htm, (2017), accessed on June 27, 2017.

[87] Li, Y. Blowing in the wind, China Dialogue (May 31, 2016), https:/www.chinadialogue.net/article/show/single/en/8965-Blowing-in-the-wind, accessed on June 26, 2017.

[88] Zhang, Y. Wind industry protest 'abandon wind to save thermal' Caixin Weekly (April 15, 2016), http://weekly.caixin.com/2016-04-15/100932361.html (in Chinese), accessed on June 26, 2017.

[89] Kahrl, F., Coal-fired generation overcapacity in China: Quantifying the scale of the problem, Regulatory Assistance Project (2016), http://www.raponline.org/wp-content/uploads/2016/05/rap-coalcapacitychina-2016-feb.pdf, accessed on July 5, 2017.

[90] Dupuy, M., China power sector reform: Key issues for the world's largest power sector, Beijing: Regulatory Assistance Project http://www.raponline.org/wp-content/uploads/2016/07/rap-dupuy-key-issues-china-power-sector -2016-march.pdf, accessed on June 18, 2017.

[91] Bradtke, M. China’s great green grid? Chris James on capturing China’s “wasted” wind and solar power, New Security Beat (June 29, 2017), https://www.newsecuritybeat.org/2017/06/chinas-great-green-grid-qa-chris-james-china-capturewasted-wind-solar-power, accessed on July 5, 2017.

[92] Liu, C. Facing grid constraints, China puts a chill on new wind energy projects, Inside Climate 
News

(March

28,

2016),

https://insideclimatenews.org/news/28032016/china-wind-energy-projects-suspends-clean-energ y-climate-change, accessed on July 2, 2017.

[93] Dupuy, M., D. Moskovitz, F. Waston, et al., Recommendations for power sector policy in China: Practical solutions for energy, climate and air quality, Regulatory Assistance Project (2013),

http://www.raponline.org/wp-content/uploads/2016/05/rap-nextstepspowersectorpolicyinchina-e n-2013-oct.pdf, accessed on July 5, 2017.

[94] Liu, J., R. Wang, Y. Sun, Y. Lin, L. Xiao, A barrier analysis for the development of distributed energy in China: A case study in Fujian province, Energy Policy 60 (2013) 262-271.

[95] Roberts, D. By 2020, Every Chinese coal plant will be more efficient than every US coal plant: China's efforts to tackle coal are comprehensive and ambitious, a new report shows, Vox (May 16 , 2017),

https://www.vox.com/energy-and-environment/2017/5/15/15634538/china-coal-cleaner, accessed on July 1, 2017.

[96] Li, Y., Blowing in the wind, China Dialogue (May 31, 2016), https://www.chinadialogue.net/article/show/single/en/8965-Blowing-in-the-wind, accessed on June 26, 2017.

[97] Yao, K. and M. Meng, China expects to lay off 1.8 million workers in coal, steel sectors, Reuters February 29, $2016 \quad$ (2016), http://www.reuters.com/article/us-china-economy-employment-idUSKCNOW205X, accessed on July 1, 2017.

[98] Zhu J. and Z. Zhao, Scenario analysis of carbon emissions of China's electric power industry up to 2030, Energies 9 (2016) 988.

[99] Winglee, M., How China can stop wasting wind energy, China Dialogue July 22, 2016 (2016), https://www.chinadialogue.net/article/show/single/en/9119-How-China-can-stop-wasting-wind-e nergy, accessed on July 2, 2017.

[100] Nature Energy, Adjusting China's sails, Nature Energy 1 (2016), DOI:10.10.38/NENERGY.2016.110.

[101] Liu, X. and L. Kong, A new chapter in China’s electricity market reform, Policy Brief 13, Energy Study Institute, National University of Singapore (2016), http://esi.nus.edu.sg/docs/default-source/esi-policy-briefs/a-new-chapter-in-china-s-electricity-m arket-reform.pdf, accessed on June 18, 2017.

[102] Cameron-Moore, S. China sets up 100 billion yuan fund to cover layoffs in coal, steel sectors,
Reuters
February
29 ,
2016
(2016), 
http://www.reuters.com/article/us-china-economy-employment-fund-idUSKCNOW20JT?mod=r elated\&channelName=ousivMolt, accessed on July 1, 2017.

[103] Mori, A. Impact of the China-induced coal boom in Indonesia: From a resource governance perspective, in Mori, A. (ed.), China's Climate-Energy Policy: Domestic and International Impacts, Routledge, Oxon (forthcoming).

[104] NDRC, Medium and Long-Term Development Plan for Renewable Energy in China, Beijing (2007b).

[105] Mines and Communities, China and US coal disasters, (2006) http://www.minesandcommunities.org/article.php?a=1155, accessed on June 18, 2017.

[106] Xu, Y., C.J. Yang, and X. Xuan, Engineering and optimization approaches to enhance the thermal efficiency of coal electricity generation in China, Energy policy 60 (2013) 356-63.

[107] Organization for Cross-regional Coordination of Transmission Operators, Japan (OCCTO), Decision on the standard burden of cost that is evaluated as excessively high to the incumbent electric power companies in reference to the generation capacity, with regard to the Guidance of the Agency for Natural resources and Energy on the Grid Capacity Development and the Burden Sharing among Business that is Accompanied by New Generation Capacity, (April 13, 2016), www.occto.or.jp/access/oshirase/2017/2016_0413_ippan_futan_jpugengaku.html (in Japanese), accessed on June 18, 2017.

[108] IEA. China, People's Republic of: Electricity and Heat for 2014 (2017), http://www.iea.org/statistics/statisticssearch/report/?country=China\&product=electricityandheat \&year=2014, accessed on July 7, 2017.

[Note]

${ }^{1}$ Chinese government announced the renewable energy target of 10\% by 2010 and 15\% by 2020 in total primary energy consumption in 2007 [104]. It proposed the binding targets for non-fossil fuel of $11.4 \%$ by 2015 and $15 \%$ by 2020 in the $12^{\text {th }}$ Five Year Plan (FYP) in 2011. It set out the target of 20\% by 2030 in its Intended Nationally Determined Commitment (INDC) to the Paris Agreement, and more than half by 2050 in 2017.

2 This figure might be underestimate. Mines and Communities [105] estimated fifteen thousand accidents that brought twenty-five thousand deaths during the same period.

3 This program improved the average thermal efficiency in coal power so significantly that the China surpassed the United States in the efficiency in 2008 [106].

${ }^{4}$ Preferential treatment includes: financial support for grid extension and access road and preferential loan and tax conditions. Local governments also competed each other to offer upfront economic support for project owners in their geographical area, expecting huge amount of tax revenue if their bid is successful [31].

${ }^{5}$ A minimum $50 \%$ of local content requirement was imposed, which was raised up to $70 \%$ and 
made valid for non-concession projects in 2005 [30].

${ }^{6}$ Grid infrastructure is estimated to cost 27.88 billion yuan by 2015 and soar to 45.32 billion by 2020, and system balancing 31.49 billion yuan in 2015 and 63.97 billion yuan in 2020 among which a substantial part (over 60\%) comes from electricity loss in energy transfer [76].

7 UHV enables the transmission lines to deliver a large amount of electricity over long distances with lower loss [83].

8 In Japan, for example, new wind power and solar PV generators have to bear most of the cost of new transmission lines that are additionally required to dispatch their electricity from grids to end-users, not to mention to power plants to grids [107]. This effectively blocks off transformation of the prevailing system. 


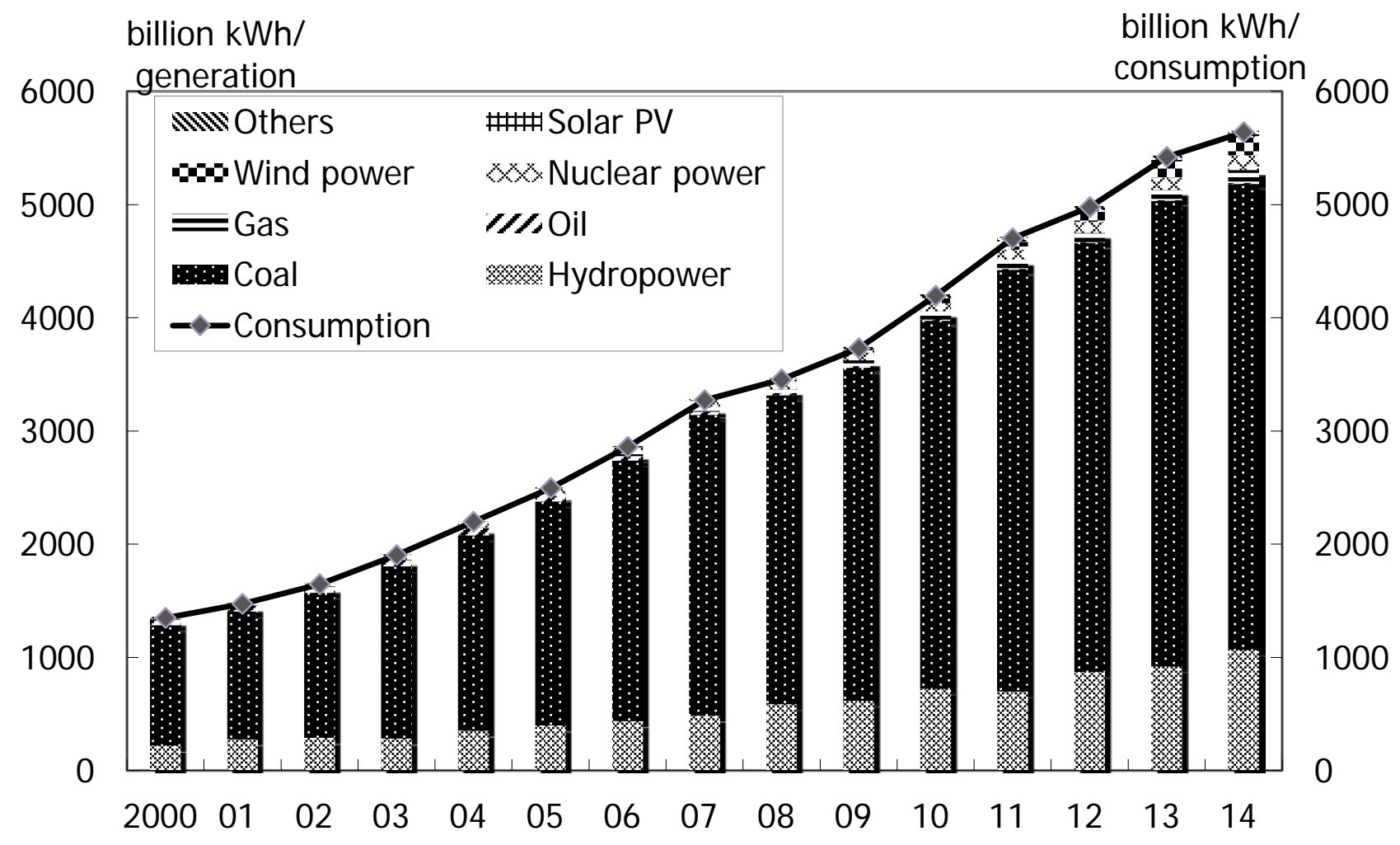

Figure 1 Power Consumption and Supply in China by Source of Energy

Source: Author compilation based on [108]. 


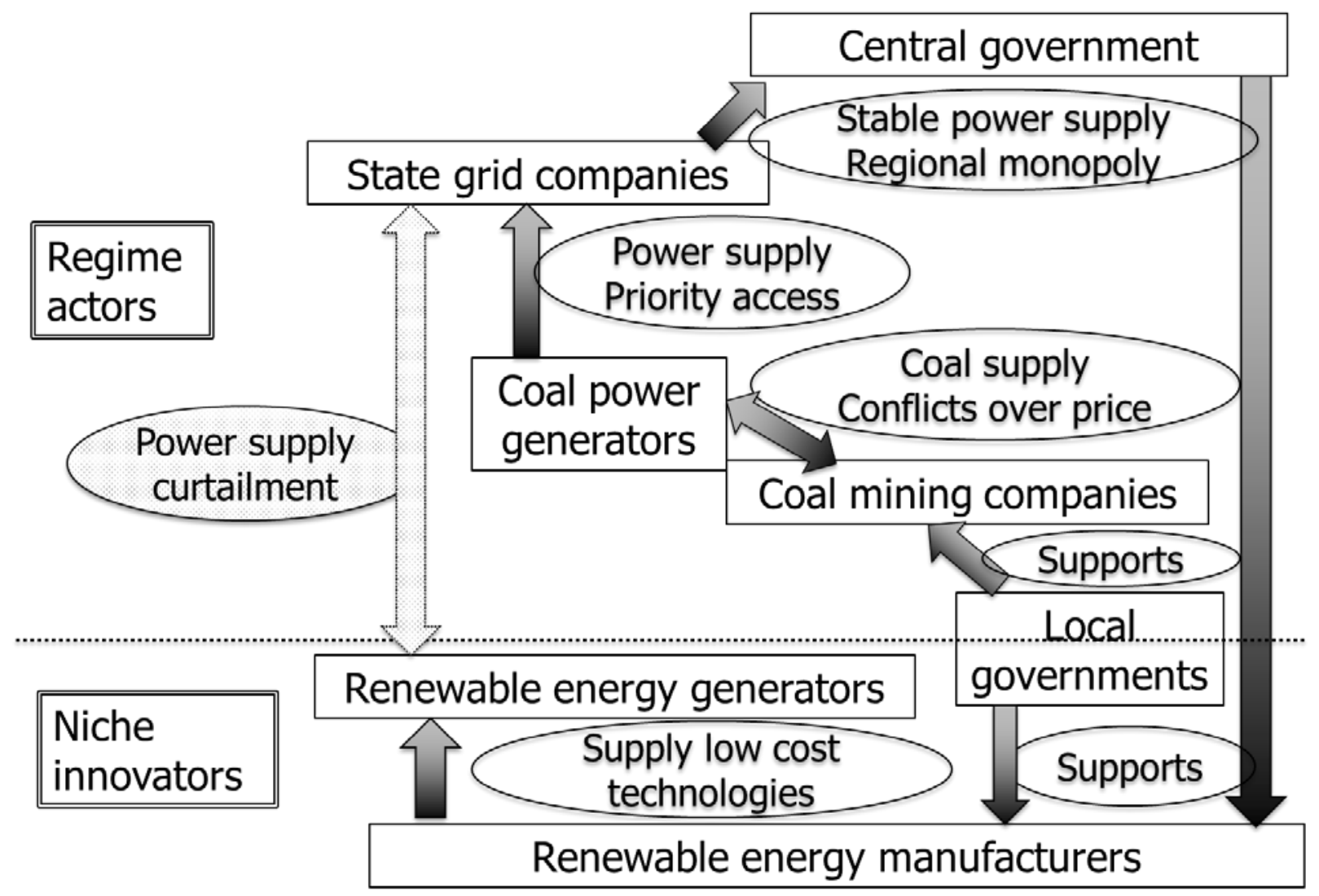

Figure 2a The Primary relationship among core stakeholders amid rapid electricity growth Source: Author. 


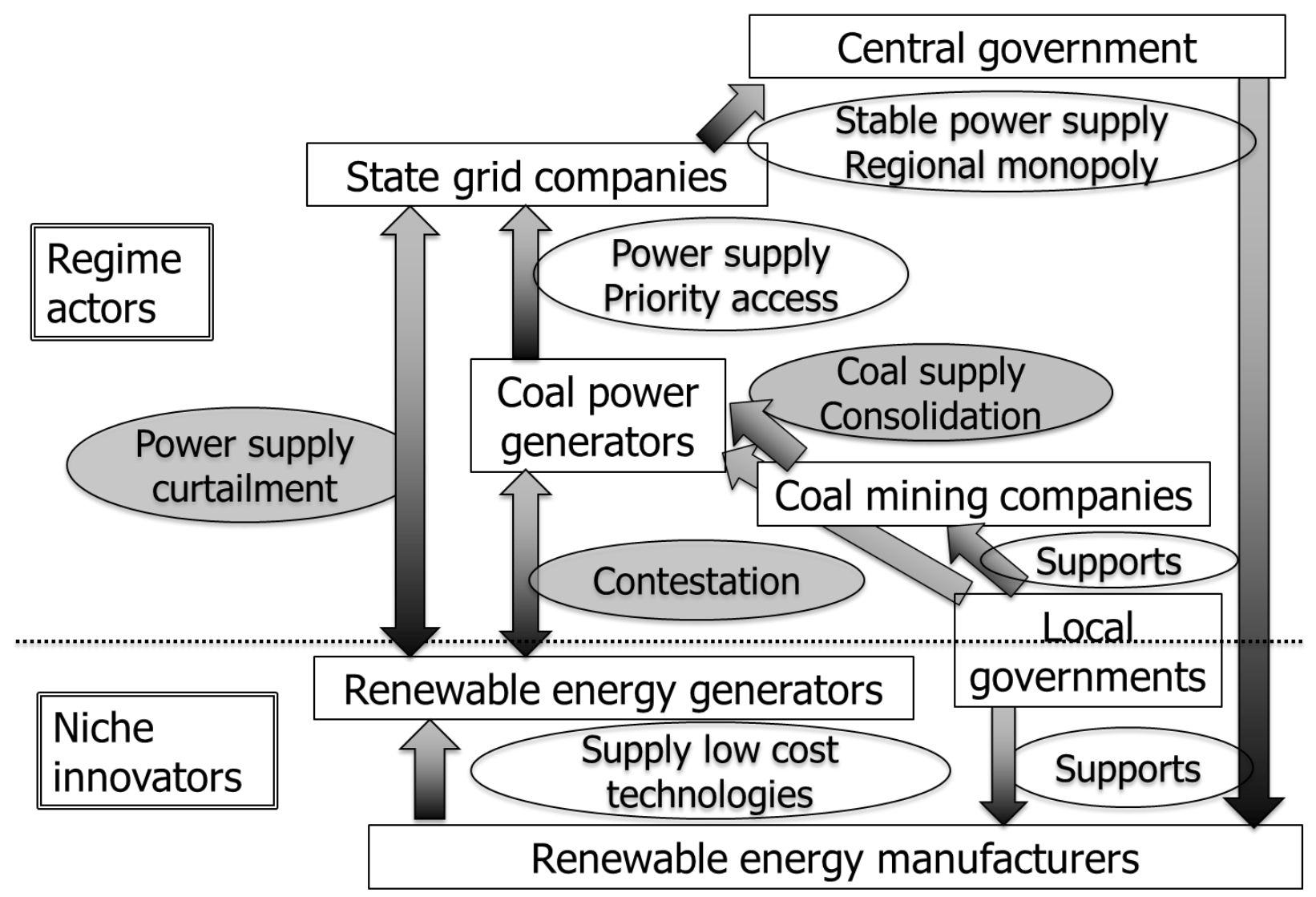

Figure $2 \mathrm{~b}$ The Primary relationship among core stakeholders in the stagnant electricity growth period Source: Author. 